\title{
Comparison of accumulation and altered steroid secretion by placental tissue treated with TCDD and natural mixture of PCDDs-PCDFs
}

\author{
K. Augustowska ${ }^{1}$, E. Łucja Gregoraszczuk ${ }^{1 *}$, A. Grochowalski², T. Milewicz ${ }^{3}$, \\ M. Mika ${ }^{4}$, J. Krzysiek ${ }^{3}$ and R. Chrząszcz ${ }^{2}$ \\ ${ }^{1}$ Laboratory of Physiology and Toxicology of Reproduction, Department of Animal Physiology, \\ Institute of Zoology, Jagiellonian University, Krakow, Poland; ${ }^{2}$ Department of Chemistry, Krakow, \\ University of Technology, Krakow, Poland; ${ }^{3}$ Department of Endocrinology and Fertility, \\ Collegium Medicum, Jagiellonian University, Krakow, Poland; and ${ }^{4}$ Department of \\ Animal Physiology, Academy of Agriculture, Kraków, Poland
}

Explants of human placental tissue harvested immediately after expulsion were used to determine differences between accumulation of 2,3,7,8-tetrachlorodibenzo-p-dioxin (TCDD) and polychlorinated dibenzo-p-dioxin (PCDD)polychlorinated dibenzo-p-furans (PCDF) environmental mixture, and their influence on placental steroidogenesis. Explants were cultured in vitro for 5 days in media supplemented each day with either TCDD or a mixture of PCDDPCDF. Media were collected every day for steroid content analysis by radioimmunoassay. At $24 \mathrm{~h}$ after the last treatment, the tissue was frozen for further analysis of the content of TCDD or other congeners present in the mixture. Determinations of TCDD and all 17 PCDDs and PCDFs were performed using gas chromatography equipped with DB-5 MS and DB-17 capillary columns. In the control tissue, the amounts of both TCDD and mixture components were close to the limit of detection of the method. In the treated tissue, the TCDD accumulation was $94 \%$ of the total exposure to TCDD. The most toxic congeners $2,3,7,8$ TCDD, 2,3,7,8-tetrachlorodibenzofuran, 1,2,3,7,8-pentachlorodibenzo-p-dioxin (PeCDD), 1,2,3,7,8-pentachloro- dibenzo-p-furans (PeCDF) and 2,3,4,7,8-PeCDF showed the highest accumulation, which covered $>50 \%$ of the total toxic equivalents present in this mixture. During the first 3 days of exposure to TCDD there was no effect on the conversion of dehydroepiandrosterone to oestradiol, whereas on days 4 and 5 of exposure, a twofold decrease in oestradiol secretion was observed. However, a small but significant increase in oestradiol secretion was noted at all times of exposure to the PCDD-PCDF mixture. All observed changes in oestradiol secretion were not accompanied by changes in progesterone secretion after exposure to TCDD or the PCDD-PCDF mixture. In conclusion, a high accumulation of TCDD in the placental tissue resulted in a decrease in oestradiol secretion and in vivo this could result in a decrease in blood flow through the placenta. From the mixture, PeCDD and PeCDF in the higher amount accumulated in the placental tissue caused an increase in oestrogen secretion and as a consequence could activate oxytocin secretion from the pituitary and early pregnancy outcome.

\section{Introduction}

2,3,7,8-tetrachlorodibenzo- $p$-dioxin (TCDD) and related compounds elicit a diverse spectrum of toxic responses. As these compounds are lipophilic and difficult to metabolize, any environmental exposure of living organisms to these congeners results in their accumulation in the fat tissue and bioconcentration in humans via the food chain. In addition, these compounds are able to pass through the human placenta (Koppe et al., 1992). Taking into account fat solubility of these compounds

${ }^{*}$ Correspondence

Email: greg@zuk.iz.uj.edu.pl and the maternal origin of $10-20 \%$ of fetal fatty acids, polychlorinated biphenyls (PCBs) and hexachlorobenzene (HCB) may impair the development of the fetus (Manchester and Jacobsy, 1984). Exposure of humans to halogenated aromatic hydrocarbons, such as polychlorinated biphenyls, is associated with adverse pregnancy outcomes, including intrauterine growth retardation, congenital structural anomalies and cognitive developmental deficits. Chen et al. (1992) and Rogan et al. (1988) observed impaired development of the fetus in women exposed to PCB, dioxins and dibenzofurans. Therefore, these compounds represent a serious health risk, especially to the fetus and infants, whose enzymatic and metabolic systems are not yet mature. 
There have been few studies on the direct effects of dioxin on placental steroidogenesis. A study by Augustowska et al. (2003) involving the primary culture of cells isolated from placental cotyledons harvested immediately after expulsion showed a difference between the action of pure TCDD and dioxin mixture on placental steroid secretion. This difference was possibly due to an additional effect of pentachlorodibenzo- $p$-dioxin (PeCDD) and pentachlorodibenzo- $p$-furan (PeCDF), which accounted for $>50 \%$ of the total toxic equivalents (TEQ) present in this mixture. However, it is not clear whether particular congeners present in the mixture accumulate in the same amounts. The present study used ex vivo culture of pieces of placental tissue in an attempt to understand the differences in the action of TCDD and dioxin mixture on placental steroidogenesis. The following were considered: (i) accumulation of pure TCDD and a mixture of polychlorinated dibenzo- $p$-dioxin (PCDD)-polychlorinated dibenzo- $p$-furans (PCDF) in the placental tissue; and (ii) the effects of repeated exposure to these compounds on placental steroidogenesis. This cultured tissue is more physiological than cell dispersed or cell lines because of the intact structure.

\section{Materials and Methods}

\section{Reagents}

Medium M199, PBS, penicillin, trypsin and calf serum were purchased from the Laboratory of Vaccines (Lublin). Dehydroepiandrosterone, cholesterol and antibiotic antimitotic solution $(\times 100)$ were obtained from Sigma Chemical Co. (St Louis, MO). 2,3,7,8-TCDD solutions were prepared by the dilution of evaporated, concentrated toluene standard (Promochem, Wesel) in dimethyl sulphoxide (DMSO). PCDD and PCDF natural congener mixture in DMSO was prepared by toluene Soxhlet extraction of $10 \mathrm{~g}$ fly ash sample collected from the hospital waste incinerator and Alumina column cleaned-up according to Grochowalski (1998). This mixture contained TCDD, PeCDD, hexachlorodibenzo- $p$-dioxin $(1,2,3$, 4,7,8-HxCDD, 1,2,3,6,7,8-HxCDD and 1,2,3,7,8,9HxCDD), 1,2,3,4,6,7,8-heptachlorodibenzo-p-dioxin (HpCDD), octachlorodibenzo- $p$-dioxin (OCDD), 2,3, 7,8-tetrachlorodibenzofuran (TCDF), pentachlorodibenzofuran (1,2,3,7,8-PeCDF and 2,3,4,7,8-PeCDF), hexachlorodibenzofuran $(1,2,3,4,7,8-\mathrm{HxCDF}, 1,2,3,6,7,8-$ HxCDF, 2,3,4,6,7,8-HxCDF and 1,2,3,7,8,9-HxCDF), heptachlorodibenzofuran $(1,2,3,4,6,7,8-\mathrm{HpCDF}$ and $1,2,3,4,7,8,9-\mathrm{HpCDF})$ and octachlorodibenzofuran (OCDF). The concentration of all 17 toxic congeners was reported and TEQ was calculated as $27.7 \mu \mathrm{g}$ TEQ $\mathrm{kg}^{-1}$ of fly ash. After extract clean-up using standard procedure on Alumina, the solvent was exchanged with DMSO to obtain the stock solution at a concentration of $10 \mathrm{ng}$ TEQ $\mathrm{ml}^{-1}$. Working solutions were prepared by a dilution of the stock solution with DMSO to obtain appropriate PCDD-PCDF concentrations just before addition to the culture medium.

Semi-permeable membranes for dialysis $(2.5 \mathrm{~cm} \times$ $20.0 \mathrm{~cm}$ polyethylene foil of $80.0 \mu \mathrm{m}$ wall thickness) purchased from Exposmeter AB Trehörningen 34SE-929 26 Tavelsjö were used after rinsing with hexane.

\section{Culture}

Placental tissue was collected in a gynaecological hospital in Krakow, Poland where the clinical information on pregnancy outcomes was obtained. Collection of placentae and recording of clinical histories followed previously established protocols that had ethical approval by a local institutional review board. Patients gave their informed consent to the study. Clinical information recorded on each pregnancy included: smoking history, neonatal mortality and pregnancy outcome. Normal term (weeks 40-42 of gestation) placentae from non-smoking women were collected for the experiment. Immediately after expulsion of the placenta, placental cotyledons were harvested, placed in ice-cold PBS and transported to the laboratory. The tissue was cut into 10-15 mg pieces and incubated in Erlenmeyer flasks containing $3 \mathrm{ml} \mathrm{M199}$ medium according to Gregoraszczuk (1990). The flasks were incubated at $37^{\circ} \mathrm{C}$ with constant shaking at 70 r.p.m. for 5 days for better penetration of the media, oxygen and also chemicals. The method of culture used in the present study permits for the examination of chemical accumulation in the tissue. This method was used to measure TCDD (Grochowalski et al., 2000a) and PCB (Gregoraszczuk et al., 2003) accumulation in the follicular wall. The percentage of proliferating cells as measured using the Molecular Immunology Borstel (MIB-I) labelling index showed $81.2 \%$ of proliferating cells in 6 days of culture, indicating that the model is suitable. Because of the intact structure present in vitro, there is a benefit to culture of pieces of placenta. This type of ex vivo culture has been successfully used for ovarian and breast cancer tissue (Devine et al., 2002; Fruehauf, 2002). Ovarian tissues have been successfully incubated for up to 50 days without visible signs of necrosis (Blandau et al., 1965).

\section{Experimental procedure}

One placental cotyledon (approximately $50 \mathrm{~g}$ ) was removed from the underlying fibrous elements. Soft villous material from the maternal surface was cut away from connective tissue and vessels, according to the procedure described by Kliman et al. (1986). In the control culture, placental tissue was cultured in Parker medium (M199) supplemented with 5\% calf serum, whereas in the experimental groups, TCDD or PCDDPCDF mixture was added daily for 4 days at a dosage of $40 \mathrm{pg}$ TEQ $\mathrm{ml}^{-1}$ from day 0 to day 4 of culture. The media in the control and experimental groups were changed 
every day, and collected and frozen for steroid analysis. The total dose was $600 \mathrm{pg}$ TEQ. At $24 \mathrm{~h}$ after the last treatment (day 5), tissue was frozen for further analysis of accumulation of TCDD and mixture components in the tissue, and the culture medium was frozen for analysis of steroid concentration. Experiments were repeated five times using cotyledons collected from five different patients.

Dehydroepiandrosterone (DHEA; $1 \mathrm{ng} \mathrm{ml}^{-1}$ ), a natural substrate for oestradiol synthesis in the placental tissue was used to measure the effect of dioxin on oestradiol production, and pregnenolone $\left(10 \mu \mathrm{g} \mathrm{ml}^{-1}\right)$ was used for its influence on progesterone secretion.

\section{Chemical analysis}

Sample clean-up was performed using semipermeable membrane, carbon column, acid-base silica and Alumina column separation according to Grochowalski et al. (2002). Determination of TCDD and all 17 PCDDs and PCDFs was performed using gas chromatography equipped with DB-5 MS and DB-17 capillary columns $(60.0 \mathrm{~m}$ in length, $0.25 \mathrm{~mm}$ inside diameter and $0.25 \mu \mathrm{m}$ of stationary phase film). For PCDD and PCDF congener detection, double fragmentation mass spectrometric detector based on Finnigan MAT GCQplus GC-MS/MS instruments operated in Collisionaly Induced Dissociation was used. Identification and confirmation was carried out on the principle of characteristic mass spectral data obtained from electron primary ions (electron impact ionization) and helium atom collision secondary ions (MS/MS mode). The limit of detection for PCDDs and PCDFs was $0.01 \mathrm{pg} \mathrm{g}^{-1}$ for $2,3,7,8$-TCDD and 2,3,7,8-TCDF (0.01 ppt) and $0.1 \mathrm{pg}$ $\mathrm{kg}^{-1}$ for OCDD and OCDF (0.1 ppt), respectively, in various sample matrices. In analytical work, $16{ }^{13}[\mathrm{C}]-$ PCDD-PCDFs were used as internal standards and for clean-up and recovery measurement.

\section{TEQ calculation}

Calculation of TEQ of the sample is based on the $2,3,7,8$-TCDD toxicity equivalent factors (TEF). The toxic or dioxin equivalent (TEQ) for a mixture was defined as the sum of the concentration of individual PCDD-PCDF times their corresponding individual toxic equivalency factors $\left(T E F_{1}\right)$ which were initially derived from enzymatic induction potency ratios ( $\mathrm{EC}_{50}$ [TCDD]/ $\mathrm{EC}_{50}$ [test compound]) using TCDD the reference toxin (that is TEF $=1$ ) according to Safe (1996).

\section{Steroid concentration analysis}

Progesterone, testosterone and oestradiol were determined by radioimmunoassay using Spectra kits (Orion, Diagnica) supplied by Polatom (Swierk). The limit of sensitivity for the progesterone assay was $94 \mathrm{pg} \mathrm{ml}^{-1}$. The interassay and intra-assay coefficients of variation were 5.8 and $2.9 \%$, respectively. The mean recoveries were $95.1-$ $103.7 \%$. The crossreactivity with pregnenolone was $2.9 \%$. All other steroids tested ( $5 \beta$-dihydroprogesterone, $20 \beta$-hydroxyprogesterone, corticosterone, testosterone and oestrone) showed $<1 \%$ crossreactivity. The limit of sensitivity for testosterone was $5 \mathrm{pg} \mathrm{ml}^{-1}$ and the interassay and intra-assay coefficients of variation were 5.4 and $5.3 \%$, respectively. The mean recoveries were $84.2-121.7 \%$. Crossreactivity with $5 \alpha$-dihydrotestosterone was $4.5 \%$. All other steroids tested (methyltestosterone, androstendione, progesterone and oestradiol) showed $<0.5 \%$ crossreactivity. The limit of sensitivity for oestrogen assay was $5 \mathrm{pg}$ and the interassay and intra-assay coefficients of variation were 10.28 and $2.9 \%$, respectively. The mean recoveries were $85.6-108.9 \%$. The crossreactivity with ethinyl oestradiol was $1.4 \%$. All other steroids tested (oestrone, oestriol, progesterone, testosterone and corticosterone) showed $<1 \%$ crossreactivity.

\section{Statistical analysis}

All data points are expressed as means \pm SEM. There were three replicates per treatment. Experiments were repeated five times using cotyledons collected from five different patients. Since the variation between the experiments was small, these results were analysed by ANOVA followed by Duncan's new multiple range test.

\section{Results}

\section{Accumulation of TCDD and PCDD-PCDF mixture}

In the control culture, the concentrations of both TCDD and mixture components were close to the limit of detection. In the experimental culture, the amount of TCDD accumulation was $94 \%$ of the total exposure.

The accumulation of particular congeners of the mixture are shown (Table 1), expressed as $\mathrm{pg} \mathrm{g}^{-1}$ tissue and as a percentage of accumulation of the total dose. The most toxic congeners, 2,3,7,8-TCDD (41.6\%), 2,3,7,8TCDF (26.31\%), 1,2,3,7,8-PeCDD (13.05\%), 1,2,3,7,8PeCDF (9.18\%) and 2,3,4,7,8-PeCDF (16.63\%), showed the highest accumulation, which accounted for $>50 \%$ of the TEQ present in this mixture. The accumulation of the remaining congeners was about $10 \%$ of the total dose.

\section{Effect of repeated doses of TCDD on oestradiol and progesterone secretion}

A significant increase in oestradiol secretion was noted on day 2 of exposure to $40 \mathrm{pg}$ TCDD ml ${ }^{-1}(P<$ $0.01)$. The situation changed with increased exposure to TCDD: a twofold decrease in oestradiol secretion was observed on days 3 and $5(P<0.01$; Fig. 1$)$. TCDD had no effect on the conversion of pregnenolone to progesterone (Fig. 2). 
Table 1. Concentration of individual PCDD-PCDF in placental tissue exposed ex vivo to PCDD-PCDF mixture administered each day for 4 days at a dose of $40 \mathrm{pg}$ TEQ $\mathrm{ml}^{-1}$

\begin{tabular}{rlcccc}
\hline Lp I & \multicolumn{1}{c}{ Congeners } & $\begin{array}{c}\mathrm{m}_{\mathrm{i}} \\
\left(\mathrm{ng} \mathrm{m}^{-1}\right)\end{array}$ & $\begin{array}{c}\text { Accumulation } \\
\left(\mathrm{ng} \mathrm{g}^{-1}\right)\end{array}$ & $\begin{array}{c}\mathrm{m}_{\mathrm{i}} \times \mathrm{TEFi} \\
\left(\mathrm{ng} \mathrm{g}^{-1}\right)\end{array}$ & $\begin{array}{r}\text { Percentage of } \\
\text { accumulation }\end{array}$ \\
\hline 1 & $2,3,7,8$ TCDD & 0.28 & 0.101 & 0.101 & 36.07 \\
2 & $1,2,3,7,8$ PeCDD & 1.74 & 0.313 & 0.313 & 17.98 \\
3 & $1,2,3,4,7,8 \mathrm{HxCDD}$ & 2.93 & 0.312 & 0.031 & 10.64 \\
4 & $1,2,3,6,7,8 \mathrm{HxCDD}$ & 4.53 & 0.49 & 0.049 & 10.81 \\
5 & $1,2,3,7,8, \mathrm{HxCDD}$ & 5.03 & 0.479 & 0.048 & 9.52 \\
6 & $1,2,3,4,6,7,8 \mathrm{HpCDD}$ & 27.58 & 2.15 & 0.021 & 7.79 \\
7 & OCDD & 27.18 & 2.779 & 0.000 & 10.22 \\
8 & $2,3,7,8 \mathrm{TCDF}$ & 1.14 & 0.283 & 0.028 & 24.82 \\
9 & $1,2,3,7,8 \mathrm{PeCDF}$ & 3.54 & 0.469 & 0.023 & 13.24 \\
10 & $2,3,4,7,8 \mathrm{PeCDF}$ & 6.69 & 1.52 & 0.760 & 22.72 \\
11 & $1,2,3,4,7,8 \mathrm{HxCDF}$ & 9.2 & 1.238 & 0.124 & 13.45 \\
12 & $1,2,3,6,7,8 \mathrm{HxCDF}$ & 8.98 & 0.659 & 0.066 & 7.33 \\
13 & $2,3,4,6,7,8 \mathrm{HxCDF}$ & 13.64 & 1.914 & 0.191 & 14.03 \\
14 & $1,2,3,7,8,9 \mathrm{HxCDF}$ & 0.83 & 0.104 & 0.010 & 12.38 \\
15 & $1,2,3,4,6,7,8 \mathrm{HpCDF}$ & 33.41 & 2.123 & 0.021 & 6.35 \\
16 & $1,2,3,4,7,8,9 \mathrm{HpCDF}$ & 5.7 & 0.557 & 0.006 & 9.77 \\
17 & OCDF & 11.92 & 0.941 & 0.000 & 7.9 \\
\hline
\end{tabular}

$\mathrm{m}_{\mathrm{i}}$ : mass of individual congeners; PCDD-PCDF: polychlorinated benzo- $p$-dioxin-polychlorinated dibenzo- $p$-furan; $\mathrm{TEF}_{\mathrm{i}}$ : toxic equivalency factors; TEQ: total toxic equivalents.

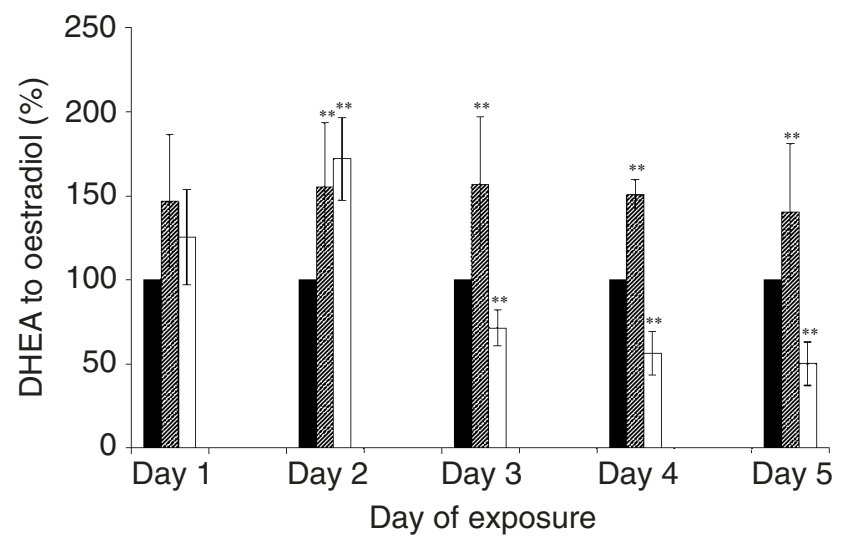

Fig. 1. Effects of 2,3,7,8-tetrachlorodibenzo-p-dioxin (TCDD;

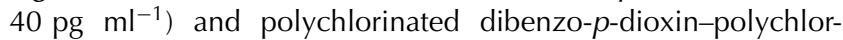
inated dibenzo- $p$-furan (PCDD-PCDF) mixture $\left(40 \mathrm{pg} \mathrm{ml}^{-1}\right)$ on conversion of dehydroepiandrosterone (DHEA; $1 \mathrm{ng} \mathrm{ml}^{-1}$ ) to oestradiol. All values are the mean \pm SE and expressed as percentage secretion, with control as $100 \%$. ${ }^{* *} P<0.01$ compared with the control. ם: DHEA; 眼: DHEA + PCDD-PCDF; $\square$ DHEA + TCDD.

\section{Effect of repeated doses of PCDD-PCDF on oestradiol and progesterone secretion}

A small, but significant increase in oestradiol secretion was noted on all days of exposure to $40 \mathrm{pg}$ TEQ $\mathrm{ml}^{-1}$ PCDD-PCDF mixture (Fig. 1). After exposure to the mixture all changes observed in oestradiol secretion were not accompanied by changes in progesterone secretion (Fig. 2).

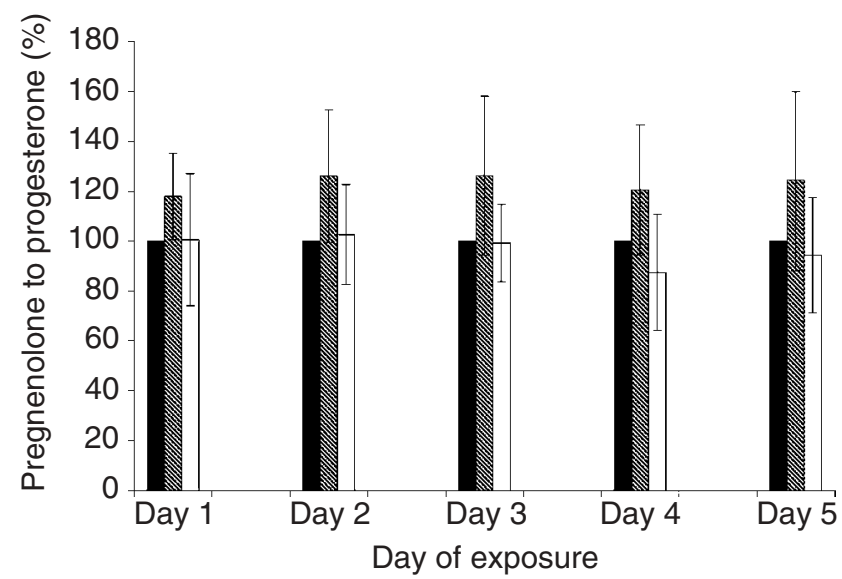

Fig. 2. Effects of 2,3,7,8-tetrachlorodibenzo- $p$-dioxin (TCDD;

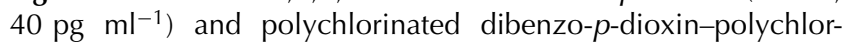
inated dibenzo- $p$-furan (PCDD-PCDF) mixture $\left(40 \mathrm{pg} \mathrm{ml}^{-1}\right)$ on conversion of pregnenolone $\left(10 \mu \mathrm{g} \mathrm{ml}^{-1}\right)$ to progesterone. All values are the mean $\pm \mathrm{SE}$ and expressed as percentage secretion, with control as $100 \%$. $\mathbf{a}$ : pregnenolone; pregnenolone + PCDDPCDF; $\square$ pregnenolone + TCDD.

\section{Discussion}

Chronic exposure to persistent endocrine disrupters results in their bioaccumulation in increasing concentrations in living organisms. The present study clearly showed differences between the accumulation of pure TCDD and a dioxin mixture. From the congeners present in the mixture, the most toxic compounds, 2,3,7,8-TCDD and 2,3,7,8-TCDF, showed the highest accumulation. 
Higher chlorinated dioxins and furans are more lipophilic than lower chlorinated compounds such as TCDD. Compounds that are more lipophilic may result in lower accumulation of TCDD in the mixture of all 17 PCDDs and PCDFs than that of pure TCDD added to the samples. The sample that was treated with the PCDDPCDF mixture showed a distribution of all 17 congeners typical of that found in the human placental tissue. This finding indicates that during the experiment all of the 17 individual congeners present in the mixture accumulate with respect to their individual solubility in fat. Moreover, some congeners may be metabolized more effectively than TCDD or TCDF. Grochowalski and Chrząszcz (2000) reported that fat tissue of fish contains mostly 2,3,7,8-substituted PCDDs and PCDFs which are less effectively metabolized. The explanation of the effect of different accumulation values for the 17 PCDDs and PCDFs may require further study with higher as well as lower concentrations of PCDD and PCDF in the mixture.

There is evidence that these toxic compounds accumulate in the human placenta (Lucier et al., 1990; Schecter et al., 1996, 1998; Grochowalski et al., 2000b). Koppe et al. (1992) showed that the placenta transports dioxins and furans from mother to fetus, and this is probably related to the fatty acid transport. Between 10 and $20 \%$ of fatty acids in a fetus at term are of maternal origin. In adipose tissue of children that died in the early neonatal period, concentrations of $25 \%$ were found of three dioxin and furan congeners 1,2,3,7,8-PeCDD, $1,2,3,6,7,8-\mathrm{HpCDD}$ and $2,3,4,7,8$-PeCDF in relation to the mean concentration of these congeners in the fat of 14 samples of breast milk.

Hagenmaier et al. (1990) noted the highest deposition for 2,3,7,8-TCDD and 1,2,3,7,8-PCDD in the infant marmoset monkey (Callithrix jacchus) after a lactation period of 33 days the mother of which has been subcutaneously administered a defined mixture of PCDD and PCDF 11 weeks before the delivery. This finding is in accordance with the results of the present study showing the highest accumulation of 2,3,7,8-TCDD and $2,3,7,8-\mathrm{TCDF}$ in the placental tissue exposed in vitro to the mixture of dioxins. Our previous data indicated a link between the increased concentration of the most toxic PCBs in the placenta and cigarette smoking during pregnancy and a tendency for an increase in PCB 156, PCB 114 and PCB124 in placentae from abnormal pregnany outcomes. DeKoning and Karmaus (2000) showed that on a lipid basis, the highest concentration of PCB in placenta was 2.8-fold higher than the highest concentration of PCB in breast milk and suggest that PCBs may be capable of crossing the placenta to a greater extent than previously believed.

As a consequence of the accumulation, an anti-oestrogenic action of TCDD was noted starting from day 3 of exposure and oestrogenic action of the mixture at all times of exposition. The human syncytial trophoblast is known to serve several roles in pregnancy. The human placenta expresses high aromatase activity. An alteration in aromatase function in the uterus has been shown to permanently affect human embryos (Simpson et al., 1994). TCDD is well known as an anti-oestrogen that enhances oestrogen metabolism (Spink et al., 1990) and decreases oestogen-induced responses such as increased uterine mass (Pohjanvirta and Tuomisto, 1994), cell proliferation (Sun and Safe, 1997) and the regulation of receptors related to the epidermal growth factor (Astroff et al., 1990), oestrogen (Wang et al., 1993) and progesterone (Harper et al., 1994).

However, humans are exposed daily to mixtures of chemicals, rather than to individual chemicals. From a public health perspective, it is most relevant to answer the question of whether the components in a mixture interact in a way that results in an increase in their overall effect compared with the sum of the effects of the individual components. Surprisingly, only a few studies have examined the effects of PCDF on reproduction and development. The results of the present study are the first to show the effects of repeated exposure to a mixture PCDD-PCDF that occurs in the environment on placental steroidogenesis. In contrast to the action of TCDD, the mixture of dioxin-furans showed small but significant oestrogenic action. It was noted that there was $50 \%$ more oestradiol in the culture medium under the influence of this mixture. In fact, oestrogen regulates lowdensity lipoprotein (LDL) uptake and P450scc and, thus, apparently is involved in generating the substrate for progesterone production within the placenta and there are reports of an increase in the oestrogen:progesterone ratio in the amniotic fluid of women during labour (Romero et al., 1988). Placental microsomes and mitochondria incubated with a single dose of oestrogen showed a decrease in progesterone formation by inhibition of 3- $\beta$ HSD (Depp et al., 1973; Ferre et al., 1975; Yoshida et al., 1989). Genti-Raimondi et al. (1983) showed that physiological doses of oestrogen had a stimulatory effect on the conversion of pregnenolone to progesterone; however, supraphysiological doses had an inhibitory effect.

The lack of action of the mixture on progesterone secretion and the oestrogenic action of the mixture on placental tissue observed in the present study should be taken into consideration in view of the study by Chen et al. (2001), who examined the transfer of polychlorinated dibenzo- $p$-dioxins, dibenzofurans (PCDFs) and nonorto biphenyls to offspring and placenta. They showed a dose-dependent increase in hepatic sequestration with TCDD, PeCDD, 4-PeCDF and OCDF. TCDD and three $\mathrm{PCBs}$ reached equilibration between the fetus and placenta.

The results of the present study are in accordance with those of McMurry and Dickerson (2001), who showed that the mixture of six different endocrine disrupters induced effects that were very different from either or both mixture components, indicating the lack of 
predictability of chemicals when combined in a mixture. In addition, Chu et al. (2001) indicated that the mixture of PCBs and TCDD may be additive or antagonistic depending on the dose and endpoints measured. The effects of a mixture of dioxins may be additive or antagonistic depending on the dose. For the purpose of predicting mixture effects, knowledge of the mechanism of action and toxicokinetics is required. Because oestriol may affect uterine cystyl aminopeptidase gene expression (Darne et al., 1987), it could contribute to the progressive increase in uterine responsiveness to xenobiotics in primate pregnancy during the third trimester of gestation, and its measurements may be of predictive value in delineating patients at risk of premature delivery (Darne et al., 1987; Romero et al., 1988).

Information concerning mechanisms of dioxin mixture action on placental cells is scarce. These preliminary experiments reported here indicate that further studies on the induction of CYP izosymes mRNA in the human placenta by these compounds are needed to understand the differences in the action of TCDD and dioxin mixture on placental steroidogenesis.

This work was supported by the KBN Grant No. 3 PO5D 08425.

\section{References}

Astroff B, Rowlands C, Dickerson R and Safe S (1990) 2,3,7,8tetrachlorodibenzo- $p$-dioxin inhibition of $17 \beta$-estradiol-induced increases in rat uterine epidermal growth factor receptor binding activity and gene expression Molecular and Cellular Endocrinology 72 247-252

Augustowska K, Gregoraszczuk EL, Milewicz T, Krzysiek J, Grochowalski A and Chrząszcz R (2003) Effects of dioxin (2,3,7,8-TCDD) and PCDD/PCDF congeners mixture on steroidogenesis in human placenta tissue culture Endocrine Regulation 37 11-19

Blandau RJ, Warrick E and Rumery RE (1965) In vitro cultivation of fetal mouse ovaries Fertility and Sterility 16 705-715

Chen CY, Hamm JT, Hass JR and Birnbauum LS (2001) Disposition of polychlorinated dibenzo- $p$-dioxins, dibenzofurans and non-ortho polychlorinated biphenyls in pregnant long evans rats and the transfer to offspring Toxicology and Applied Pharmacology 173 65-88

Chen YCJ, Guo YL and Hsu CC (1992) Cognate development of Yu-Cheng ('oil disease') children prenatally exposed to heat-degraded PCBs Journal of the American Medical Association 268 3213-3218

Chu I, Lecavalier P, Hakansson H, Yagminas A, Valli VE, Poon P and Feeley M (2001) Mixture effects of 2,3,7,8-tetrachlorodibenzo- $p$-dioxin and polychlorinated biphenyl congeners in rats Chemosphere 43 807-814

Darne J, McGarrigle HHG and Lachelin GCL (1987) Increased saliva estradiol to progesterone ratio before idiopathic preterm delivery: a possible predictor for preterm labor? British Medical Journal 294270 272

DeKoning EP and Karmaus W (2000) PCB exposure in utero and via breast milk. A review Journal of Exposure Analysis and Environmental Epidemiology 10 285-293

Depp R, Cox DW, Pion RJ, Conrad SH and Heinrichs WL (1973) Inhibition of the pregnenolone delta 5-3 beta hydroxysteroid dehydrogenase-delta 54 isomerase systems of human placenta and corpus luteum of pregnancy Gynecologic Investigation 4 106-120

Devine PJ, Rajapaksa KS and Hoyer PB (2002) In vitro ovarian tissue and organ culture: a review Frontiers in Bioscience 7 1979-1989

Ferre F, Breuiller $\mathbf{M}$ and Cedard L (1975) Human placental delta5-3beta hydroxysteroid dehydrogenase activity (delta5-3beta HSDH): intracellular distribution, kinetic properties, retroinhibition and influence of membrane dilapidation Steroids 26 551-570
Fruehauf JP (2002) In vitro assay-assisted treatment selection for women with breast or ovarian cancer Endocrine-Related Cancer 9 171-182

Genti-Raimondi S, Patrito LC and Flury A (1983) Effect of estradiol-17 $\beta$ on the conversion of pregnenolone to progesterone in human term placenta incubated in vitro. Steroids 41 467-474

Gregoraszczuk EL (1990) The advantage of the aggregate culture of isolated ovarian cell types over monolayer culture Cytotechnology 4 19552000

Gregoraszczuk EL, Grochowalski A, Chrząszcz R and Wegiel M (2003) Congener-specific accumulation of polychlorinated biphenyls in ovarian follicular wall follows repeated exposure to PCB 126 and PCB 153. Comparison of tissue levels of PCB and biological changes Chemosphere $50481-488$

Grochowalski A (1998) PCDDs and PCDFs concentration in combustion gases and bottom ash from incineration of hospital wastes in Poland Chemosphere 37 2279-2291

Grochowalski A and Chrzązzcz R (2000) The result of the large scale determination of PCDDs, PCDFs and coplanar PCBs in Polish food product samples using GC-MS/MS technique Organohalogen Compounds 47 306-310

Grochowalski A, Piekło R, Gasińska A, Chrząszcz R and Gregoraszczuk EL (2000a) Acumulation of 2,3,7,8-tetrachlorodibenzo-p-dioxin (TCDD) in porcine preovulatory follicles after in vitro exposure to TCDD: effect on steroid secretion and cell proliferation Cytobios 102 21-31

Grochowalski A, Milewicz T, Krzywda A, Krzysiek J and Gregoraszczuk EL (2000b) Polychlorinated biphenyls in placental tissue from normal versus abnormal pregnency outcomes: preliminary results Polish Journal of Gynaecological Investigations 3 71-74

Grochowalski A, Chrząszcz R and Węgiel M (2002) Determination of polychlorinated dibenzodioxins and dibenzofurans in food using gas chromatography and double fragmentation mass spectrometry (GCMS/MS) 8th International Symposium on Separation Sciences - Toruń, Poland L-18 75-83

Hagenmaier H, Wiesmuller T, Golor G, Krowke R, Helge $H$ and Neubert D (1990) Transfer of various polychlorinated dibenzo-p-dioxin (PCDDs and $\mathrm{PCDFs}$ ) via placenta and milk in marmoset monkey Archives of Toxicology 64 601-615

Harper N, Wang X, Liu H and Safe S (1994) Inhibition of estrogeninduced progesterone receptor in MCF-7 human breast cancer cells by aryl hydrocarbon (Ah) receptor agonists Molecular and Cellular Endocrinology 104 47-55

Kliman HJ, Nestler JE, Sermasi E, Sanger JM and Strauss JF 3rd (1986) Purification, characterization, and in vitro differentiation of cytotrophoblasts from human term placentae Endocrinology 1181567 1582

Koppe JG, Olie K and van Wijnen J (1992) Placental transport of dioxins from mother to foetus. II. PCBs, dioxins and furans and vitamin K metabolism Developmental Pharmacology and Therapeutics 18 9-13

Lucier GW, Sunahara GI and Wong TK (1990) Placental markers of humane exposure to polychlorinated biphenyls: implications for risk assessment IARC Scientific Publications 104 55-62

McMurry CS and Dickerson RL (2001) Effects of binary mixture of six xenobiotics on hormone concentrations and morphometric endpoints of northern bobwhite quail (Colinus virginianus) Chemosphere 43829 837

Manchester DK and Jacobsy E (1984) Decreased placental monooxygenase activities associated with birth defects Teratology 30 31-37

Pohjanvirta R and Tuomisto J (1994) Short-term toxicity of 2,3,7,8tetrachlorodibenzo- $p$-dioxin in laboratory animals: effects, mechanism and animal models Pharmacological Reviews 46 483-549

Rogan WJ, Gladen BC, Hung KL, Doong SL, Shih LY, Taylor JS, Wu YC, Young D and Ragan NB (1988) Congenital poisoning by polychlorinated biphenyls and their contaminants in Taiwan Science 241 334-336

Romero R, Scoccia B, Mazor M, Wu YYK and Benveniste R (1988) Evidence for a local change in the progesterone/estrogen ratio in human parturition American Journal of Obstetrics and Gynecology 159 657-660

Safe SH (1996) Development validation and problems with the toxic equivalency factor approach for risk assessment of dioxins and related compounds Journal of Animal Science 76 134-141 
Schecter A, Startin J, Wright C, Papke O, Ball M and Lis AQ (1996) Concentrations of polychlorinated dibenzo- $p$-dioxins and dibenzofurans in human placental and fetal tissues from the U.S. and in placentas from Yu-Cheng exposed mothers Chemosphere 32 551-557

Schecter A, Kassis I and Papke O (1998) Partitioning of dioxins, dibenzofurans and coplanar $\mathrm{PCB}_{\mathrm{s}}$ in blood, milk, adipose tissue, placenta and cord blood from five American women Chemosphere 37 1817-1823

Simpson ER, Mahendroo MS, Means GD et al. (1994) Aromatase cytochrome P450, the enzyme responsible for estrogen biosynthesis Endocrine Reviews 15 342-355

Spink DC, Lincoln DW, Dickerman HW and Gierth JF (1990) 2,3,7,8tetrachlorodibenzo- $p$-dioxin cause an extensive alteration of $17 \beta$ estradiol matabolism in humane breast cancer cells Proceedings National Academy of Sciences USA 87 6917-6921

Sun G and Safe S (1997) Antiestrogenic activities of alternate-substituted polychlorinated dibenzofurans in MCF-7 human breast cancer cells Cancer Chemotherapy and Pharmacology 40 239-244

Wang X, Porter W, Krishnan R, Narasimhan TR and Safe S (1993) Mechanism of 2,3,7,8-terachlorodibenzo-pdioxin (TCDD)-mediated decrease of the nuclear estrogen receptor in MCF-7 human breast cancer cells Molecular and Cellular Endocrinology 96 159-166

Yoshida H, Nakai S, Nimbari F, Yoshimoto K and Nishimura T (1989) Synthesis of 11 alpha-hydroxyprogesterone haptens Steroids $\mathbf{5 3} 727-$ 738

Received 23 April 2003.

First decision 30 June 2003.

Revised manuscript received 18 July 2003.

Accepted 4 August 2003. 